\title{
Children's caring roles and responsibilities within the family in Africa
}

Article

Accepted Version

Evans, R. (2010) Children's caring roles and responsibilities within the family in Africa. Geography Compass, 4 (10). pp. 1477-1496. ISSN 1749-8198 doi:

https://doi.org/10.1111/j.1749-8198.2010.00386.x Available at https://centaur.reading.ac.uk/6096/

It is advisable to refer to the publisher's version if you intend to cite from the work. See Guidance on citing.

To link to this article DOI: http://dx.doi.org/10.1111/j.1749-8198.2010.00386.x

Publisher: Wiley-Blackwell

All outputs in CentAUR are protected by Intellectual Property Rights law, including copyright law. Copyright and IPR is retained by the creators or other copyright holders. Terms and conditions for use of this material are defined in the End User Agreement.

\section{www.reading.ac.uk/centaur}

\section{CentAUR}

Central Archive at the University of Reading

Reading's research outputs online 


\title{
Geography Compass
}

\section{Children's caring roles and responsibilities within the family in Africa}

\section{Ruth Evans}

\section{Department of Geography and Environmental Science, University of Reading}

\begin{abstract}
In many Sub-Saharan African countries, the care of chronically ill, disabled or elderly relatives is usually regarded as the responsibility of family members, within a broader landscape of often overburdened healthcare systems, the expense of medical fees, very limited access to social protection and policies that emphasise home-based care. Recent studies have demonstrated that children and youth, particularly girls and young women, take on considerable caring roles for chronically ill and elderly relatives in Africa. This article reviews the available research on young people's caring roles and responsibilities within families affected by chronic illness and disability in Sub-Saharan Africa. I discuss how children's caring roles challenge global and local constructions of childhood and suggest ways of conceptualising the socio-spatial and embodied dimensions of children's everyday care work within diverse household forms. I analyse evidence on outcomes of care and children's resilience in managing their caring responsibilities and examine the complex array of processes that influence whether children take on caring roles within the family. I argue that relational, intergenerational and lifecourse approaches to researching children's caring responsibilities within the family have considerable potential for future geographical research and could provide further insights into the ways that care is embedded in social relations,


cultural norms and structural inequalities operating in different configurations in particular places.

\section{Introduction}

In many Sub-Saharan African countries, the care of chronically ill, disabled or elderly relatives is usually regarded as the responsibility of family members and located within the home (Evans and Thomas, 2009). Socio-cultural expectations of care are reinforced by the broader landscape of often overburdened healthcare systems, the expense of medical fees, very limited access to social protection and policies that emphasise home-based care (Ogden et al., 2006). Commentators have argued that global processes of restructuring and neoliberal economic policies such as reductions in public health spending and the privatisation of care provision implicitly increase women's and children's unpaid care work within the family (Robson, 2004a; Sparr, 1994). Furthermore, over three decades of the HIV and AIDS epidemic have had major impacts on the material and emotional resources available to families and communities struggling to care for people with chronic, life-limiting illness, despite rapid improvements in access to anti-retroviral treatment for people living with HIV in many African countries in recent years (WHO, 2009). The gendered nature of the 'burden of care' of people with HIV and AIDS-related illness in Sub-Saharan Africa is receiving increasing attention in policy discourses (Peacock and Weston, 2008; Akintola, 2004) and grassroots adult carers are being mobilised in several African countries through the UNDPsupported Home-Based Care Alliance (Esplen, 2009). However, children's involvement in caring for family members is rarely acknowledged in such policy and advocacy initiatives. 
No official statistics about the scale of young caregiving in Africa currently exist, although a quantitative study is currently underway in South Africa (Cluver and Operario, 2008). A large survey conducted in Tanzania in the 1990s found that around 4\% of 7-14 year olds were reported to have cared for sick relatives in the previous seven days (Ainsworth et al., 2000, cited in Robson et al., 2006, p.97). Statistical evidence suggests that between $2 \%$ to $4 \%$ of children take on caring roles in the UK, Australia and the USA (Becker, 2007). Given the high numbers of disabled people and the fact that they are disproportionately represented among the 'poorest of the poor' in the global South (McEwan and Butler, 2007; Yeo and Moore, 2003), the increased number of people living with HIV and requiring care since the early 1990s, combined with very limited access to formal support and the fact that in 2007 , children (aged under 18) constituted 50\% of the population of Sub-Saharan Africa (UNICEF, 2008), it is likely that well over $4 \%$ of children in many African countries may regularly be involved in caring for parents, siblings and relatives who have a need for care related to illness, disability, young or old age.

Within the extensive body of research on orphanhood and the social impacts of HIV and AIDS in Africa, children's active roles in providing care for family members have been largely overlooked. However, a small but growing body of research has started to investigate young people's significant caring responsibilities and contributions to households affected by AIDS in East and Southern Africa (Robson, 2000; 2004a; Robson and Ansell, 2000; Robson et al., 2006; Evans and Becker, 2009; Evans and Thomas, 2009; Skovdal et al., 2009; Bauman et al., 2006; Cluver and Operario, 2008; Bray, 2009). Other studies, while not 
explicitly focused on children's care work, have demonstrated that children and youth, particularly girls and young women, take on considerable caring roles for sick and elderly relatives in Africa (Evans, 2005; Young and Ansell, 2003; Chimwaza and Watkins, 2004; Steinberg et al., 2002; Van Blerk and Ansell, 2007). Indeed, a survey of 771 AIDS-affected households in South Africa found that children under the age of 18, the majority of whom were girls, were responsible for caring for a family member with AIDS-related illness in approximately $8 \%$ of households (Steinberg et al., 2002). Research has also highlighted the particular circumstances of young people living in child- and youth-headed households (Luzze and Ssedyabule, 2004; Francis-Chizororo, 2008; Germann, 2005; Kesby et al., 2006; Thurman et al., 2006; 2008; Payne, 2009; Bell and Payne, 2009; Evans, forthcoming), a phenomenon that has been linked (although not exclusively: see Meintjes et al., 2010 and Thurman et al., 2009) to high levels of orphanhood and changing household structures as communities adapt to the epidemic in the most affected regions of East and Southern Africa (Foster et al., 1997; Bourdillon, 2004).

While the severity of the HIV and AIDS epidemic and the implications for caring practices within particular cultural contexts need to be recognised (Nyambedha et al., 2003; Oleke et $a l ., 2005)$, studies focused on children's caring roles in Africa to date have almost exclusively been framed within the context of the HIV and AIDS epidemic in East and Southern Africa. This has resulted in a paucity of studies investigating children's caring roles in the broader field of disability, ageing and development across Africa. Not withstanding this criticism, this article reviews the available research and draws on the broader literature on geographies of children and youth and research with young carers in the global North in order to 
conceptualise young people's caring roles, relations, practices and outcomes of care within families affected by chronic illness and disability in Sub-Saharan Africa. Firstly, I discuss the ways that children's caring roles challenge global and local constructions of childhood. I then discuss ways of conceptualising the socio-spatial and embodied dimensions of children's everyday care work in Africa, based on research evidence about children's responsibilities within diverse household structures. I outline the key findings of research in relation to outcomes of care and children's resilience and examine the complex array of factors and processes influencing whether children take on caring roles within the family at a range of spatial scales. I conclude by highlighting a number of areas for future research to develop our understandings of socio-spatial and temporal caring practices, relations and outcomes of care for young people and their families across Africa.

\section{Constructions of childhood, social reproductive work and care within the family}

Feminist geographers have highlighted the importance of understanding the everyday sociospatial dimensions of women's and children's social reproductive work (Brydon and Chant, 1989; Momsen, 2004; Katz, 1993; 2004). Geographies of children and youth have demonstrated that children often make significant contributions to the household's productive and reproductive work in the global South, challenging universal models of childhood as a period in which children are cared for within the family home and their time is spent predominantly in full-time education and recreation in preparation for a productive 'adult' life (Katz, 2004; Punch, 2001; 2002, Robson, 2004b; Ansell, 2005). Research has shown that in Africa, the tasks performed by girls and younger boys tend to be the low-status activities usually undertaken by women, such as household chores, load bearing and subsistence 
agriculture (Kielland and Tovo, 2006; Bradley, 1993). Furthermore, girls and boys are often socialized to perform different household tasks according to a traditional gendered division of labour and hierarchies of age and sibling birth order, which has differential impacts on boys' and girls' spatial mobility and time (Katz, 1993; Omari and Mbilinyi, 1997; Koda, 2000) . Despite making significant contributions to their families, however, both boys and girls generally occupy a weak bargaining position within the household, are excluded from decision-making processes and are rarely treated as equals to adults within the community (Koda, 2000; Panelli et al., 2007; Evans, forthcoming).

In many African societies, care work is highly gendered, with women and girls usually considered to be the primary carers due to their assumed 'natural' roles as 'nurturers' (Evans and Thomas, 2009; Robson, 2004a). Care is therefore often conceptualised as a moral duty, founded on love, emotional attachments and reciprocal kinship responsibilities, rather than monetary exchange (Becker, 2007). The notion of children as 'carers' threatens Western ideological constructions of childhood as "a 'carefree phase of innocence, in which children are free from 'adult' responsibilities and work" as well as "norms of parenting that define children as being dependent on their mothers (and fathers) for nurturing, care and socialisation" (Evans, in press, p.3). According to African socio-cultural concepts of childhood and care, children, families and communities have reciprocal rights and responsibilities as part of an 'intergenerational contract' to provide care and support during sickness and old age (van Blerk and Ansell, 2007; Laird, 2005). However, in some instances, parental ill health, disability or death combined with a lack of alternative support, means that children may be called on to care for family members and fulfil familial responsibilities as 
part of the intergenerational contract at a much younger age than would usually be expected. Young people's caring roles therefore defy both global and local understandings of childhood and conventional intergenerational relations and young people who care for a disabled family member in Africa often have low social status and little access to formal resources to support their care work. Indeed, young people's 'in-between place between global and local discourses of childhood and youth' (Evans, forthcoming) may result in stigma, marginalisation and isolation within the community (Francis-Chizororo, 2008; Kesby et al., 2006; Thurman et al., 2008; Evans and Becker, 2009). This reveals how care is culturally defined (Tronto, 1993) and varies according to norms of gender, age and intergenerational norms in different places. The following section proposes ways of conceptualising the everyday caring activities that African young people engage in within different household structures and family forms.

\section{Conceptualising African young people's everyday care work within and beyond the}

\section{social space of the household}

Despite socio-cultural constructions of care, Becker (2007, p.24) comments, 'unpaid caregiving is labour', and, 'recognising these activities as care work is to politicize and to make public the activities, roles, value and outcomes that characterise unpaid and familyhidden caregiving, and to identify these issues as concerns for social and public policy and for social development'. In both the global North and South, Becker (2007) suggests that the work that "young carers" ${ }^{\text {"1 }}$ do is distinct from the usual household work that young people engage in because of the wider range of household and caring tasks undertaken by 'young carers', particularly children's involvement in the personal or 'intimate' care of their 
parent/relative, as well as the frequency, time spent and outcomes of these tasks. Becker (2007) suggests that children's informal caring in the global North and South can be conceptualised as a continuum, ranging from 'caring about' to 'caring for' ${ }^{2}$ a family member, along which all children's caregiving activity can be located (see Figure 1). Young carers would be placed at the 'high' end of the continuum, that is, 'caring for' a family member, which involves substantial, regular and significant caregiving activities, usually for a coresident relative 'in relations of very intimate proximity' (Barnett and Land, 2007, p.1066), with evidence of significant negative outcomes. The continuum distinguishes young people's unpaid caring roles and responsibilities within the family from the responsibilities of most children by suggesting that care work at the 'high' end goes beyond cultural expectations of children's contributions to their household, with respect to norms of age, gender and generational relations among others.

Recent research in Sub-Saharan Africa has revealed that children's care work in families affected by HIV and AIDS goes beyond the usual expectations of children's household responsibilities (Robson et al., 2006; Bauman et al., 2006; Bray, 2009). Evans and Becker's (2009) research in Tanzania and the UK highlighted the fluid nature of children's caring responsibilities for parents with HIV, as children's caring roles shift along the continuum over time and space, depending on the changing need for care and access to informal and formal safety nets in specific socio-cultural, geographical and welfare contexts.

Figure 1: A continuum of young caregiving (adapted from Evans and Becker, 2009, p.26)

CRuth Evans 10/5/10. Please cite article as: Evans, R. (2010) 'Children's caring roles and responsibilities within the family in Africa’, Geography Compass, 4(10): 1477-1496. 


\begin{tabular}{|c|c|c|}
\hline $\begin{array}{l}\text { Low levels of } \\
\text { caregiving and } \\
\text { responsibility }\end{array}$ & & $\begin{array}{l}\text { High levels of } \\
\text { caregiving and } \\
\text { responsibility }\end{array}$ \\
\hline 'Caring about' & \multirow{4}{*}{$\begin{array}{c}\text { Caregiving tasks and } \\
\text { responsibilities increase/decrease } \\
\text { in amount, regularity, complexity, } \\
\text { time involved (hours per week), } \\
\text { intimacy and duration (months } \\
\text { and years) }\end{array}$} & 'Caring for' \\
\hline $\begin{array}{l}\text { Most children and } \\
\text { young people }\end{array}$ & & Few children and youth \\
\hline $\begin{array}{l}\text { 'Routine' levels and } \\
\text { types of caregiving } \\
\text { including some help } \\
\text { with instrumental } \\
\text { activities of daily } \\
\text { living }^{3} \\
\end{array}$ & & $\begin{array}{l}\text { 'Substantial, regular and } \\
\text { significant' caregiving } \\
\text { including considerable } \\
\text { help with instrumental } \\
\text { activities of daily living }\end{array}$ \\
\hline $\begin{array}{l}\text { Household tasks and } \\
\text { caregiving tasks can be } \\
\text { considered culturally } \\
\text { appropriate, according } \\
\text { to norms of age, gender } \\
\text { and generational } \\
\text { relations etc. }\end{array}$ & & $\begin{array}{l}\text { Household tasks and } \\
\text { caregiving tasks can be } \\
\text { considered culturally } \\
\text { inappropriate, according } \\
\text { to norms of age, gender } \\
\text { and generational } \\
\text { relations etc. }\end{array}$ \\
\hline \multirow[t]{2}{*}{$\begin{array}{l}\text { Children and young } \\
\text { people providing a few } \\
\text { hours of care and } \\
\text { support each week with } \\
\text { no evidence of negative } \\
\text { outcomes } \\
\end{array}$} & & $\begin{array}{l}\text { Young carers providing } \\
\text { 'full-time' caregiving } \\
\text { each week with evidence } \\
\text { of significant negative } \\
\text { outcomes }\end{array}$ \\
\hline & $\begin{array}{l}\text { Many 'hidden' young carers } \\
\text { (unknown to service provide }\end{array}$ & no support) \\
\hline
\end{tabular}

ORuth Evans 10/5/10. Please cite article as: Evans, R. (2010) 'Children's caring roles and responsibilities within the family in Africa', Geography Compass, 4(10): 1477-1496. 
In Table 1, I categorise the socio-spatial and embodied dimensions of young people's everyday care work in Africa, based on the available research evidence about children's caring responsibilities within diverse household structures. It is important to note that these dimensions vary in different spatial and temporal contexts, as I discuss below in relation to the categories in Table 1.

Table 1: Socio-spatial and embodied dimensions of children's and young people's everyday care work in Africa

(adapted from Evans and Becker, 2009 and Evans, forthcoming).

\begin{tabular}{|c|c|}
\hline Caring & Examples \\
\hline $\begin{array}{l}\text { Household } \\
\text { chores }\end{array}$ & $\begin{array}{l}\text { Cooking, washing dishes, sweeping, cleaning and tidying, fetching water and } \\
\text { firewood, laundry, heating water for baths, shopping, cultivating food for } \\
\text { consumption, tending livestock, cutting wood, running errands }\end{array}$ \\
\hline Health care & $\begin{array}{l}\text { Reminding parent/sibling/ relative to take medication, giving and collecting } \\
\text { medication, accompanying them to hospital and providing care while in hospital, } \\
\text { assisting with mobility, preparing special nutritional food, cleaning, treating and } \\
\text { dressing sores, infections and wounds, massaging the body }\end{array}$ \\
\hline $\begin{array}{l}\text { Personal } \\
\text { care }\end{array}$ & Washing/bathing parent/relative, assisting to eat, dress and use the toilet \\
\hline Child care & $\begin{array}{l}\text { Getting siblings ready for school, bathing siblings, supervision, resolving } \\
\text { arguments and conflict between siblings, help with school work }\end{array}$ \\
\hline Emotional & Talking and comforting parent/sibling/ relative, giving advice and guidance, \\
\hline
\end{tabular}

CRuth Evans 10/5/10. Please cite article as: Evans, R. (2010) 'Children's caring roles and responsibilities within the family in Africa’, Geography Compass, 4(10): 1477-1496. 


\begin{tabular}{|c|c|}
\hline support & 'being there' for them \\
\hline Self care & $\begin{array}{l}\text { Personal care of self, taking medication, getting ready for school, private study, } \\
\text { personal development, training, developing life skills and livelihood strategies etc. }\end{array}$ \\
\hline $\begin{array}{l}\text { Income- } \\
\text { generation } \\
\text { activities }\end{array}$ & $\begin{array}{l}\text { Cultivating crops and produce for sale, rearing livestock, casual agricultural and } \\
\text { construction work, fishing, working in a factory, shop or bar, selling produce, } \\
\text { cooked food, charcoal and other goods, domestic work, running errands for } \\
\text { neighbours, begging }\end{array}$ \\
\hline $\begin{array}{l}\text { Household } \\
\text { management }\end{array}$ & $\begin{array}{l}\text { Allocating tasks, paying school contributions, organising school/vocational } \\
\text { training, reminding parent/sibling/relative about appointments, paying bills and } \\
\text { resolving financial problems, budgeting, future planning and decision-making }\end{array}$ \\
\hline $\begin{array}{l}\text { Community } \\
\text { engagement }\end{array}$ & $\begin{array}{l}\text { Maintaining social networks, seeking support from and cooperating with relatives, } \\
\text { neighbours, friends, NGOs, members of faith community, participating in } \\
\text { neighbourhood, school, faith community, youth and NGO meetings, activities, } \\
\text { celebrations and events. }\end{array}$ \\
\hline
\end{tabular}

Most dimensions of children's everyday care work (seven of the nine categories of caring activities listed in Table 1) are focused predominantly in and around the social space of the household, with the exception of income generation and community engagement activities that are usually reliant on young people's interactions and mobility beyond the immediate household. However, several aspects of children's household chores and healthcare support for their relative may involve reproductive work and mobility outside the household which may provide opportunities to socialise with their peers and siblings, such as fetching water, collecting wood, subsistence agriculture, going to the market or collecting medicine and/or 
providing food/ care within a hospital/clinic setting, in addition to young people's income generation and community engagement activities.

Although most children in Sub-Saharan African countries regularly undertake domestic tasks, research suggests that children with caring responsibilities carry out a wider range of household chores according to a daily routine and these are more time consuming than for children living in households without a chronically ill or disabled relative. Young people with caring responsibilities in Zimbabwe, Lesotho, Tanzania and Kenya reported significant and regular responsibilities for many household chores (Robson, 2000; Robson et al., 2006; Bauman et al, 2006; Evans and Becker, 2009; Skovdal et al., 2009). Domestic chores are likely to be particularly time-consuming and require additional resources in households affected by chronic illness or disability, especially in rural areas, and this is often compounded by a lack of basic services such as clean water (Ogden et al., 2006). Despite the usual gendered division of labour within households, young people's household chores in Tanzania did not differ significantly according to gender; although a slightly higher proportion of girls and boys were involved in activities focused around the household or outdoors respectively, both genders were equally involved in some activities traditionally perceived as 'women's work', such as washing dishes, making tea and fetching water (Evans and Becker, 2009).

Research has highlighted the significance of children's roles in providing healthcare for parents/relatives with HIV within the home as well as responding to emergencies and nursing parents/relatives during periods of serious ill health (Evans and Becker, 2009; Robson, 2000; 
Skovdal et al., 2009). Many young people in Tanzania helped their parent/relative to adhere to anti-retroviral drug regimes and, owing to the fluctuating nature of HIV-related illness, young people's regular responsibilities for household chores were often interspersed with periods of more intensive care for their parent/relative during episodes of parental ill health or hospitalisation. Furthermore, in the absence of adequate home-based care, nursing and palliative care programmes in Africa, many young people may provide intensive nursing and personal care for parents/relatives with HIV and other life-limiting illnesses at the end of their lives. The high level of healthcare support that children provide clearly distinguishes their roles and responsibilities from those of children living in households unaffected by chronic illness or impairment. The narrative of Good $\operatorname{Luck}^{4}$ (aged 18), who cared for his mother in the final stages of AIDS-related illness illustrates the intimate, highly embodied nature of young people's caring roles in this context:

Her health started deteriorating slowly. She would be poorly one day and would be better the next day and would resume doing her usual chores at home. She also ran a small business. Later she became very poorly and couldn't get out of bed. So that is when I started caring for her full time. [...] I used to bathe her, she didn't mind that I was a boy. When it was time to go to hospital I would take her there. When she was very poorly and couldn't walk, I used to carry her. Sometimes she wasn't able to eat on her own, so I would feed her. When she vomited, I used to wash the soiled clothing. Later when she disclosed her status to me, the doctors gave me gloves for washing soiled clothing and some for using when bathing her and tending her sores. So, that is how I cared for her until she died (Evans and Becker, 2009, p.138).

CRuth Evans 10/5/10. Please cite article as: Evans, R. (2010) 'Children's caring roles and responsibilities within the family in Africa', Geography Compass, 4(10): 1477-1496. 
Children's assistance with the personal care of parents/relatives is a further aspect of their care work that clearly distinguishes their responsibilities from those of other children (Becker, 2007; Robson et al., 2006). Gender matching between caregiver and care-recipient is culturally preferred, especially when providing intimate personal care, due to cultural taboos about sexuality and bodily intimacy (Robson, 2004a; Evans, in press). However, almost as many boys (aged under 18) interviewed in Tanzania provided care for their mothers/ female relatives as the number of girls (Evans and Becker, 2009). While there was evidence of a preference for gender matching when children provided personal care, girls and boys sometimes provided personal care for a parent/relative of a different gender, despite the fact that this subverted cultural boundaries of bodily intimacy across genders and generations (see example of Good Luck above). While boys' and young men's involvement in care may destabilise conventional gendered constructions of care and the meanings associated with masculinity, this was at an individual rather than societal level (ibid). Furthermore, boys and young men may be subjected to stigmatisation, bullying and harassment because their caring roles transgress gender as well as age norms, as research in the UK has also revealed (Becker and Becker, 2008).

Research with young carers in the UK acknowledges that 'childcare' is often one of the caring tasks that children perform to assist disabled parents (Becker et al, 1998; Dearden and Becker, 2004). Older siblings' significant roles in caring for younger siblings and in socialisation and providing informal training have been widely documented in many African 
societies (Cicirelli, 1994; LeVine et al, 1996; Weisner, 1982). In Tanzania, young people regularly assisted their parent with HIV in providing childcare for younger children in the household (usually their siblings and sometimes cousins), some of whom were also living with HIV (Evans and Becker, 2009). Girls appeared to be more likely to provide childcare and often spent longer looking after younger siblings than boys in these families. For young people heading households without a co-resident adult, childcare of younger siblings may represent a key focus of their care work. Research with young people heading households in Tanzania, Uganda (Evans, forthcoming) and Zambia (Bell and Payne, 2009) revealed that young people provided moral guidance and informal teaching to their siblings, resolved arguments and tried to meet their siblings' emotional and material needs, as they attempted to fulfil the parental role their mother or father would have performed if they were still alive. Older siblings in Tanzania and Uganda sought to maintain intra-generational hierarchies of age and sibling birth order in order to manage younger siblings' behaviour and maintain a position of respect as the eldest sibling heading the household (Evans, forthcoming).

Research with children caring for parents with a range of impairments in the UK has identified emotional support as a significant aspect of their caring roles (Aldridge and Becker, 2003; Dearden and Becker, 2004). Research in Tanzania (Evans and Becker, 2009), Namibia (Thomas, 2006; Evans and Thomas, 2009) and Zimbabwe (Bauman et al., 2006) has revealed that many young people provide emotional support to parents/relatives with HIV, including talking and comforting them, giving hope and reassurance, offering advice, being a confidante, keeping them company and 'being there' for them. Evans and Becker's (2009) research found that young people were more likely to provide emotional support to their 
parent/relative when they were aware of their parent/relative's HIV status. Furthermore, young people often engage in considerable 'emotion work' to manage their presentation of self and protect the person they are caring for from the emotional demands of their care work (Evans and Thomas, 2009; Evans, forthcoming).

The term 'self care" is useful in categorising a range of individual, embodied activities for which children are usually expected to take increasing responsibility as they grow older, but which in the absence of adult caregivers, they may perform without adult support or guidance. This may include hygiene and personal care, taking medication (which may be particularly important for children living with HIV and needing to adhere to a strict antiretroviral drug regime), getting ready for school, taking time out for oneself, developing life skills and engaging in other personal development activities with little adult supervision or involvement. Evans' (forthcoming) research suggests this concept is particularly relevant for orphaned young people who live independently in sibling-headed households. Although the pilot research was based on a very small sample, young people heading households in Tanzania and Uganda reported spending an average of 24 hours per week in self-care activities, in addition to time spent on their other caring tasks. The concept is also likely to be relevant when parents/adult relatives may not be able to fulfil their usual intergenerational parenting roles due to mental health problems and/or drug or alcohol use problems (although little research to date has investigated children's care work in these contexts in Africa ${ }^{6}$ ).

Income generation activities emerged as an important difference between children's caring responsibilities in the global North and South (Evans and Becker, 2009). While many young 
people living in poor households are likely to engage in income generation activities in SubSaharan Africa ${ }^{7}$, casual labour and work in the informal sector represents a key element of children's care work in households affected by disability, as children seek to replace household income lost through a parent's/ adult relative's illness, impairment or death. This is often a crucial dimension of the caring responsibilities of orphaned young people living in sibling-headed and grandparent-headed households. Evans' (forthcoming) research with sibling-headed households revealed that many young people, especially young men, often perceived their caring role predominantly in terms of providing financial support for themselves and their younger siblings. Boys and young men heading households in Uganda and Tanzania reported that they spent on average 34 hours per week working to support the family, while girls and young women heading households in contrast spent much less time (average of 11 hours a week) engaging in income-generation activities ${ }^{8}$, due to gendered constructions of care and inequalities in access to employment opportunities.

The breadwinning role of young people who head households is often closely linked to their role in managing the household and making decisions. As Bell and Payne (2009) note, historically notions of household headship have been based on income-generation. In Payne's study of child-headed households in Zambia, income earning represented an 'especially "powerful" responsibility', as this gave young people 'control and authority in terms of decision-making around household finances and more generally' (Bell and Payne, 2009, p.1032). However, the level of young people's economic contributions to the household did not always determine which sibling was regarded as the 'overall leader and decision-maker' (ibid). As research with children caring for parents with HIV has also found, young people's 
individual attributes, competences and aptitudes for particular caring tasks (in this instance, leadership, decision-making, organisational and budgeting skills) were also significant in influencing children's responsibilities within the family, in addition to hierarchies of age, sibling birth order and gender (Evans and Becker, 2009).

For children caring for parents/adult relatives, household management tasks are likely to be a less significant aspect of their care work, since disabled parents/ adult relatives usually retain their position of power within the household, in accordance with wider generational norms and age hierarchies. Thus, parents/relatives maintain overall authority and responsibility for decision-making about household resources and other matters, in spite of their illness or impairment (Robson et al., 2006; Evans and Becker, 2009) and provide guidance to children to enact these decisions. Indeed, some support workers in Tanzania perceived young people's roles as independent decision-makers who lacked adult guidance as the key distinguishing feature of their caring roles in sibling-headed households, in comparison to children caring for ill or disabled parents/adult relatives:

The child who is head of the household has the responsibility of caring for her/his siblings and caring for herself/himself. S/he has no parents, s/he is a decision maker, decides what to do in order to have success in their daily life. But the one who has a father, when s/he gets stuck s/he will ask her/his parent, I wanted to do this and that and I am stuck, what should I do? Although the father is sick, he will advise her/him. This is different from the other one who has no adviser. S/he has no one to tell her/him anything or anyone to ask ${ }^{9}$ (see Evans, forthcoming).

CRuth Evans 10/5/10. Please cite article as: Evans, R. (2010) 'Children's caring roles and responsibilities within the family in Africa', Geography Compass, 4(10): 1477-1496. 
Research from East and Southern Africa has highlighted the ways that young people's care work is embedded in social relations and reciprocal responsibilities beyond the immediate household (Thurman et al., 2006; 2009; Germann, 2005; Skovdal et al., 2009; Evans and Becker, 2009; Evans, forthcoming). Since the 1990s, gender and development commentators have called for recognition not just of women's reproductive and productive roles, but also of their 'community managing' roles in maintaining social networks and engaging in community events and development processes (Moser, 1989; Momsen, 1991). Given the importance of young people's social networks and access to informal and formal resources in sustaining households affected by chronic illness and disability, it seems appropriate to include the category of 'community engagement' as a key dimension of young people's everyday care work. Young people caring for siblings in Uganda and Tanzania confirmed the relevance of this element of their care work in participatory workshops ${ }^{9}$ and this category also appears to have wider relevance for children caring in other situations.

The category of community engagement may also be significant in analysing outcomes of care for children, in terms of spatial mobility, opportunities for play and peer interactions and integration within the community. Research from the UK suggests that young carers' spatial mobility in the wider community, engagements with their peers and opportunities to take part in leisure and other opportunities may be restricted due to their caring responsibilities within the home (Dearden and Becker, 1995; 1998; 2004; Thomas et al., 2003; Evans, in press). In Evans and Becker's (2009) research, few young people, parents or service providers in Tanzania mentioned reduced spatial mobility or restrictions on the time they could spend 
with friends due to caring responsibilities. However, some children expressed a preference to stay at home, close to their parent/relative, so that they could respond to their parent/relative's requests for assistance when needed, rather than spending time with their peers away from the household (ibid). Furthermore, some young people reported experiences of stigmatisation and ostracisism by their peers and neighbours due to their close proximity to a parent/relative with HIV (discussed in the next section).

The article thus far has pointed to ways of conceptualising and analysing the socio-spatial and embodied dimensions of children's everyday care work in Africa and noted some of the spatial and temporal impacts on children's lives. The following section analyses in more depth the available research evidence about outcomes of care and the ways these activities may affect different domains of children's lives.

\section{Outcomes of care and resilience}

Much of the research on young carers in the UK and other countries in the global North has drawn attention to negative outcomes of care for children's education, health, emotional wellbeing, social lives and transitions to adulthood (Becker et al. 1998; Dearden and Becker, 1995, 1998, 2004; Frank et al. 1999; Aldridge and Becker, 2003; Thomas et al. 2003; Becker and Becker, 2008). In common with this literature, the emerging body of research on children's care work in Africa has tended to focus on the impacts of care on children's lives and identified a range of negative outcomes that are broadly comparable to or are considered more severe than those experienced by young carers in the global North (Evans and Becker, 2009; Robson et al., 2006; Bauman et al., 2006; Bray, 2009). This is due to the fact that 
children's care work in Africa is often located at the high end of the continuum of young caregiving (see Figure 1), within a broader context of widespread poverty and lack of formal support systems in many African countries.

Studies in Tanzania, Zimbabwe, South Africa and Rwanda have identified negative impacts of care for children's emotional wellbeing, in terms of anxiety about a parent/relative's illness, anticipatory and unresolved grief (Evans and Becker, 2009; Donald and Clacherty, 2005), depression (Bauman et al., 2006; 2009; Boris et al., 2008), poor self worth and poor internal locus of control (Donald and Clacherty, 2005). Despite close relationships within the family in Tanzania, some young people caring for parents with HIV and some siblings heading households found their responsibilities overwhelming and felt unable to share their emotions with others (Evans and Becker; Evans, forthcoming). In Tanzania and South Africa, research has suggested negative outcomes of care for children's physical health and welfare, such as hunger and undernourishment (Bray, 2009), tiredness, fatigue and reduced access to healthcare (Evans and Becker, 2009). Studies in Tanzania, Uganda and South Africa have also identified the small risk of children becoming infected with HIV through direct nursing of family members with HIV, accidents in the home, combined with children's often limited knowledge of modes of HIV transmission and lack of medical supplies (such as gloves) to protect carers (ibid; Bray, 2009; Akintola, 2004).

Within the domain of the family, negative impacts identified in Tanzania and Namibia included tensions in adapting to changed roles and responsibilities and discriminatory and antagonistic relationships with parents, siblings and relatives (Evans and Becker, 2009; Evans 
and Thomas, 2009). In Uganda, Tanzania, Zimbabwe and Namibia, some young people had direct experiences of isolation, ostracism and stigmatisation within the extended family, including loss of property, that were related to their caring relations and proximity to their relative with HIV (Evans and Becker, 2009; Evans and Thomas, 2009; Evans, forthcoming; Save the Children, 2006 cited in Bray 2009). Furthermore, young people participating in these and other studies (Robson et al., 2006; Evans, 2005) reported experiences of stigmatisation, bullying and harassment by their peers and other community members linked to their caring roles and the stigma of poverty, orphanhood and AIDS.

In terms of educational impacts, research from Zimbabwe (Bauman et al., 2006), Namibia (Thomas, 2006), Tanzania (Robson et al., 2006; Evans and Becker, 2009), Uganda (ILO and Government of Uganda, 2004 cited in Bray, 2009; Evans, forthcoming) and Kenya (Skovdal et al., 2009) found that the school attendance of many young people was regularly disrupted by their care work, with children having to miss sometimes considerable periods of schooling due to their parent/ relative's need for care. Children's academic performance and long term educational outcomes may be affected, as they found it difficult to concentrate because of tiredness or anxiety about their parent/relative, missed exams and lacked adequate time for private study (Evans and Becker, 2009; Skovdal and Ogotu, 2009). Many young people in Tanzania found negotiating time and space for private study difficult when they were caring for sick parents/relatives within often overcrowded home environments, having to study late at night or early in the morning (Evans and Becker, 2009). For example, Maureen ${ }^{4}$ (aged 19) explained: 
I used to leave [school] at 2.30pm to come home. When I got home, I would prepare something for them [mother and step-father] for them to eat, wash mum's fungus, wash the soiled clothing because she used to relieve herself in bed. So I couldn't do any homework with all that going on. Then I had to prepare the evening meal, bathe dad while he criticised me. I tried to study at night, but my dad would complain that the lamp was disturbing him so he couldn't sleep. So I had to put out the light and go to bed (ibid, p.180).

Maureen felt that the conflict between her school work and caring responsibilities had led to her failure in the school leaving examinations (ibid).

Studies in Tanzania (Evans and Becker, 2009; Robson et al., 2006), Uganda (Evans, forthcoming) and South Africa (Akintola, 2004) also suggest that young people with caring responsibilities experiencing extreme poverty may be less likely to complete primary or secondary education than their peers, although as Bray (2009) notes, there is a lack of quantitative evidence to support these mainly qualitative findings. Care work may also have negative impacts on young people's transitions to adulthood, such as poor employment prospects, long term emotional impacts, risks of early pregnancy, sexual abuse and exploitation, crime and alcohol/drug use problems (Evans and Becker, 2009; Evans, forthcoming).

Evans and Becker (2009) note that it is difficult to distinguish the negative impacts of caring from wider processes of poverty, social exclusion and marginalisation that many children 
living in households where family members have HIV and AIDS (and other illnesses and impairments) are likely to experience. Research in Africa has also revealed that caring may be associated with positive outcomes which help to promote children's resilience (Evans, 2005; Evans and Becker, 2009; Skovdal et al., 2009; Bray, 2009). Indeed, researchers have increasingly called for children's care work to be theorised from a resilience perspective (Newman, 2002a; Evans, 2005; Becker, 2007), since this may help to explain individual differences among children in 'getting by' (Backett-Milburn et al., 2008) and managing their caring responsibilities. Rather than focusing on risk, the concept of resilience emphasises people's strengths in coping with adversity and their agency in engaging with protective factors that may help to reduce their vulnerability (Rutter, 1990; Howard et al., 1999; Newman, 2002b). Protective factors may be associated with individual attributes, family characteristics or the community/ wider institutional environment (see Evans and Becker, 2009 for further discussion of these concepts).

Positive outcomes of children's care work identified in Africa include: developing children's knowledge and understanding about their parent's/relative's illness or disability; a sense of responsibility, maturity, self-esteem and pride in taking on a socially valued caring role; fostering closer family relationships; and a range of life, social and care-related skills and personal qualities, such as empathy, listening and responsiveness (Evans and Becker, 2009; Robson et al., 2006; Skovdal et al., 2009; Bauman et al., 2006; Donald and Clacherty, 2005). Skovdal et al. (2009, p.592) suggest that young people in Kenya 'constructed positive carer identities' based on local cultural understandings of 'childhood as a period of duty and service'. Furthermore, in Kenya and Tanzania, caring did not appear to have any significant 
effects on some young people's school attendance or academic performance (Skovdal et al., 2009; Evans and Becker, 2009). Young people usually managed to combine schooling with their caring responsibilities. Educational resilience appeared to be related more to informal support from parents, peers and individual teachers, young people's high aspirations and level of interest and motivation, rather than supportive institutional environments or awareness of young caregiving among teachers (ibid).

In several studies, the quality of the relationship between the child and person they care for and the strength of children's social ties and access to peer and social support in the community are identified as key factors that may help to protect children from the negative impacts of caregiving (Robson et al., 2006; Evans and Becker, 2009; Evans, forthcoming; Skovdal et al., 2009; Thurman et al., 2006; 2008; Bray, 2009). Evans and Becker's (2009) research found that parents with HIV continue to maintain their important parenting role, in terms of providing love, emotional support, guidance and discipline to their children, even when they are very sick and rely on their children to care for them. In contrast, as noted earlier, young people caring for siblings without a co-resident adult often lacked a close loving relationship with a parent/adult relative who could provide emotional support and guidance (Evans, forthcoming; Francis-Chizororo, 2008), and thus young people heading households in such contexts appear to be particularly vulnerable to negative outcomes.

While research has helpfully started to document the positive as well as negative outcomes of care for young people, it remains unclear how and to what extent positive experiences may protect children in the longer term (Bray, 2009). Furthermore, while children who take on a 
caring role may develop resilience that helps to protect them psychologically and socially, Bray (2009, p.30) suggests that younger siblings of children with caring responsibilities could be 'highly vulnerable', since they witness the 'chronic and debilitating illness' of parents/relatives, but do not benefit from developing closer emotional ties through a caring role or gain from a sense of responsibility, pride and emotional maturity.

\section{Processes and factors influencing children's caring roles within families}

Having explored the ways that children's caring responsibilities affect their lives, this section focuses on the factors and processes that influence why individual children take on caring roles within families in particular places. Robson's (2000; 2004a) qualitative research with young people (aged 15-17) caring for ill family members in Zimbabwe suggested that the 'push and pull' factors for young caring identified in the young carers literature in the UK (Becker et al., 1998) were relevant in the context of Sub-Saharan Africa. Factors influencing whether children become young carers in Zimbabwe included: 'the degree of illness, availability of support services, poverty, family structure, co-residence, status/power, gender, age, educational level and income-earning ability' (Robson, 2000, p.67). Robson (2000; 2004a) and Evans and Becker (2009) link children's everyday experiences of caring in SubSaharan Africa at the micro-level to broader processes of global economic restructuring, the HIV and AIDS epidemic and policies that 'download responsibility for care' onto women, children, families and communities (Ogden et al., 2006, p.333).

Evans and Becker (2009) suggest that the factors influencing children's involvement in caregiving can be conceptualised as a dynamic interaction of individual, relational and

CRuth Evans 10/5/10. Please cite article as: Evans, R. (2010) 'Children's caring roles and responsibilities within the family in Africa’, Geography Compass, 4(10): 1477-1496. 
structural processes operating at a range of spatial scales. They suggest that global forces such as the HIV and AIDS epidemic, economic liberalisation and migration, global and national policies and interventions, as well as socio-cultural beliefs and values structure the macro environment in which young caregiving takes place. At the community level, the availability of formal and informal safety nets significantly influences whether young people take on caring roles and can potentially alleviate or increase the extent of their care work. Micro-level factors such as the parent/relative's health, disclosure of their health status, poverty and changes in household structure, as well as individual differences for young people, such as gender, age and sibling birth order, the quality of their relationship with the parent/relative they care for, personal attributes and co-residence are likely to have significant influences on whether children take on caring roles and the extent of their care work. Evans and Becker (2009) emphasise that young people negotiate their caring trajectories within both the constraints and the possibilities of these complex processes and factors and may embrace, resist or contest the identity of carer and the responsibilities and expectations placed on them in specific temporal and spatial contexts. This raises questions about how we investigate children's caring responsibilities and their capacity to act within particular places, while taking account of the broader 'macro-scale, structure-based geographies of childhood as shaped by broad-brush political-economic and social-cultural transformations' (Philo, 2000, p. 253; see also Ansell, 2009).

\section{Conclusion: future geographies of young caregiving in Africa?}

This article has sought to conceptualise the socio-spatial and embodied dimensions of children's and young people's everyday caring roles, activities and outcomes in Africa at a

CRuth Evans 10/5/10. Please cite article as: Evans, R. (2010) 'Children's caring roles and responsibilities within the family in Africa’, Geography Compass, 4(10): 1477-1496. 
range of spatial scales and provide an overview of the available research, linking with the literature on young carers in the global North and geographies of children and youth. Although research is only just starting to explore the spatialities and temporalities of young people's care work in Sub-Saharan Africa, geographers could make significant contributions to such analyses in future. In this concluding section, I highlight themes raised by the research discussed that connect to wider debates within geographies of children and youth and geographies of care and point to some potential avenues for future research.

The rapidly growing research interest in children's caring responsibilities in Africa has been largely instigated by a wider research and policy interest in the social impacts of orphanhood and AIDS in Sub-Saharan Africa, resulting in a geographical focus on children's care work in the regions most affected by the epidemic in East and Southern Africa. Many of the insights gained through mainly qualitative and participatory research with children caring in households affected by HIV and AIDS are relevant to theorising caring relations in families experiencing other impairments or illnesses and in other geographical locations. However, future research focused more broadly on children's caring roles in relation to disability and ageing in Africa could help to unravel the commonalities and differences between children's caring roles and outcomes for family members affected by a highly stigmatised, chronic and life limiting illness, such as HIV and AIDS, and children's caring roles and outcomes for parents/relatives with a broad range of impairments and needs for care. Indeed, there is a need both to quantify the extent, nature and outcomes of children's care work in African countries, as well as to further qualitative understandings of caring practices, relations and outcomes in order to make visible children's caring roles and to inform policy and 
development interventions to support this group of marginalised young people and their families (Becker, 2007).

In particular, the quality of the relationship between children and those they care for, especially the close bonds that develop between children caring for parents/adult relatives, has been highlighted as a crucial factor that may protect children from negative outcomes of care (Evans and Becker, 2009; Bray, 2009). This raises questions about the resilience and vulnerability of young people with caring responsibilities who lack or have irregular/unpredictable access to a significant adult relative who is able to provide love, emotional support and guidance, as well as about the resilience of younger siblings who do not take on caring roles within the family. Research has only recently started to explore the caring experiences of young people heading households without a co-resident adult and little research to date has investigated relations, practices and outcomes for children caring for parents/relatives with mental health problems or for those with drug or alcohol use problems.

In response to recent calls for geographies of children and youth to shift towards a more relational approach to age and intergenerationality (Hopkins and Pain, 2007; Vanderbeck, 2007), future research on children's caring roles in Africa could fruitfully explore how young people negotiate caring practices and inter- and intra-generational power relations with those they care for and others in the community. In particular, research to date suggests that there may be significant differences between children's situation depending on the generational caring relations and interdependencies that develop within particular household forms in particular places. The socio-spatial practices, relations and outcomes of care for children 
caring for a parent with a chronic illness or impairment are likely to differ significantly from those of orphaned children caring for an elderly grandparent or from those of children caring for their siblings independently without a co-resident adult relative. Patterns of mobility, the fluid nature of household structures combined with the devastating impacts of the AIDS epidemic in East and Southern Africa mean that young people may find themselves taking on caring roles in all of these situations, as their caring pathways change over time. There is much scope for further research in Africa and elsewhere to explore the influence of inter- and intra-generational power dynamics and diverse caring relations on the socio-spatiality of children's caring roles, outcomes and changing trajectories over time.

This relational and intergenerational approach to theorising children's caring roles also speaks to recent calls for a lifecourse perspective informed by a time-space framework (Bowlby et al., 2010) in order to examine the diverse, often contradictory nature of young people's pathways and transitions between the generational boundaries of 'childhood', 'youth' and 'adulthood' (Hopkins and Pain, 2007; Evans, 2008; McIlwaine and Datta, 2007). Punch (2002) develops the idea of 'negotiated interdependence' to conceptualise the relational nature of young people's transitions to adulthood. Evans (forthcoming) research reveals the highly relational and embodied nature of the life transitions in which young people are engaged. By taking on 'adult' caring roles and responsibilities that do not conform to Western or African constructions of childhood, young people blur the boundaries of 'childhood', 'youth' and 'adulthood', subverting conventional notions of children's dependence on adults and demonstrating their agency (ibid). As geographies of African youth have demonstrated (Ansell, 2004; Chant and Jones, 2005; Christiansen et al., 2006; De Boeck 
and Honwana, 2005; van Blerk, 2008), the multiple transitions in which young people caring for family members are engaged are likely to be influenced by inequalities of gender, age, class, disability, ethnicity, sexuality and locality among others.

Drawing on Tronto's (1993) ethic of care perspective, Evans and Becker's (2009) research highlighted the interdependent nature of caring relations, acknowledging that there is no fixed division of roles between 'care-givers' and 'care-receivers'. The reciprocal nature of care and high level of responsiveness, particularly in terms of mutual emotional support, has been most clearly demonstrated to date in caring relations between children and parents (Evans and Thomas, 2009; Aldridge and Becker, 2003). While caring practices, emotions and social interactions between caregivers and care-receivers were often characterised by Tronto's (1993) four ethical values of attentiveness, responsibility, competence and responsiveness, research with families affected by HIV and AIDS revealed that carers' competence to provide good care in Africa was undermined by poverty, insufficient material resources and the need to sustain livelihood activities, which sometimes resulted in conflicts and tensions within caring relationships (Evans and Thomas, 2009). Further research on the interdependencies, emotional interactions, meanings and quality of relationships within families experiencing disability and a need for care could make significant contributions to the broader fields of emotional geographies, geographies of care and disability. Additionally, research in Africa suggests that caring responsibilities and activities are often shared and negotiated between different family members (including siblings, parents, grandparents, aunts, uncles and so on) in a range of household forms (Evans and Becker, 2009). Greater understanding of the ways that family members of all ages and generations negotiate household chores, caring 
responsibilities and decision-making processes within and beyond the social space of the household would connect geographies of children and youth to more sociological perspectives on family relations and provide insights into geographies of intimacy and the 'family' which Valentine (2008, p.2097) argues have remained an 'absent presence' in geography to date.

Finally, while children's caring roles may remain the key focus of research, a more relational approach to age and an ethic of care perspective (Tronto, 1993) foreground the importance of seeking to understand the perspectives of those being cared for, as well as those providing care, which will necessarily have implications for research methodologies and approaches. Research, policy and development interventions therefore need to recognise the ways that care is embedded in social relations, cultural norms and structural inequalities operating in different configurations in particular places.

\section{Acknowledgements}

I wish to thank all the young people, parents/relatives and service providers in Tanzania and Uganda who participated in the research I undertook reported here (funded by the ESRC, RGS-IBG and University of Reading). Special thanks to Saul Becker for his helpful suggestions to clarify the continuum of young caregiving and comments on an earlier version of the article. I would also like to thank Sophie Bowlby, Elsbeth Robson, Cheryl McEwan and the reviewers for their constructive feedback. 


\section{Notes}

1. Becker (2000, p.378) defines young carers as: "Children and young persons under 18 who provide or intend to provide care, assistance or support to another family member. They carry out, often on a regular basis, significant or substantial caring tasks and assume a level of responsibility that would usually be associated with an adult. The person receiving care is often a parent but can be a sibling, grandparent or other relative who is disabled, has some chronic illness, mental health problem or other condition connected with a need for care, support or supervision”.

2. A distinction is often made in the literature between 'caring about' and 'caring for' (Noddings, 1984; Ungerson, 1983). 'Caring for' others implies that care is performed directly through everyday practices of care 'in relations of very intimate proximity', whereas 'caring about' others implies that care is less direct and may be performed at a distance (Barnett and Land, 2007, p.1066).

3. Several researchers draw a distinction between young people's involvement in 'instrumental activities of daily living' (such as shopping, cleaning, household chores) and the more care-related 'activities of daily living' (such as personal care and assisting with mobility) (Morrow, 2005; Becker, 2007). Becker (2007, p.32) comments, "The evidence from developed and developing countries indicates that many young carers have to perform more tasks (and spend longer on them) that are Instrumental Activities of Daily Living (such as shopping and housework) in addition to the more care-related Activities of Daily Living (such as intimate and personal care)”.

4. Young people's accounts have been anonymised with pseudonyms to protect their identity. 
5. The concept of 'self care' has been used to date predominantly in research in the global North within the medical/ nursing literature in terms of the management of particular chronic illnesses or medical conditions (eg. Gaut and Keickhefer, 1988) and within child development literature, in terms of so-called 'latch-key children' and parental decisions to leave children unsupervised in out-of-school settings (eg. Cain and Hofferth, 1989; Casper and Kristin, 2004).

6. Payne's (2009) research with child-headed households in Zambia included children living with a parent with alcohol use problems.

7. Over a quarter (26\%) of children aged 5-14 were estimated to be economically active in Sub-Saharan Africa in 2004, a far greater proportion than in any other continent (worldwide average of 16\%) (ILO, 2006). Economic activity is defined as 'Most productive activities undertaken by children whether for the market or not, paid or unpaid, for a few hours or full time, on a casual or regular basis, legal or illegal...To be counted as economically active, a child must have worked for at least one hour on any day during a seven-day reference period' (ILO, 2006: 6).

8. These time allocations cannot be seen as representative of young people heading households, since the pilot research was based on a very small sample of 14 young people heading households in Tanzania and Uganda. The significant difference between young men's and young women's reports of the time they spent on income-generation activities is nevertheless revealing.

9. Research findings from the author's pilot research with young people caring for their siblings in child- and youth-headed households in Tanzania and Uganda (supported with a Small Research Grant by the Royal Geographical Society with the Institute of British 
Geographers and by the School of Human and Environmental Sciences, University of Reading).

Ruth Evans is a Lecturer in Human Geography at the Department of Geography, University of Reading, UK. Her research interests include: caring relations in families experiencing disability and chronic illness, sibling care and life transitions in East and Southern Africa, childhood, care and migration in the UK, social exclusion/ inclusion and the participation of children and young people in research and policy. Her book, Children Caring for Parents with HIV and AIDS: Global Issues and Policy Responses (2009, co-authored with Saul Becker) draws on findings from an Economic and Social Research Council study of the experiences of children caring for parents and relatives with HIV in Tanzania and the UK. She has recently completed a qualitative and participatory research project with young people caring for their siblings in child- and youth- headed households in Tanzania and Uganda (funded by the University of Reading and the Royal Geographical Society, with the Institute of British Geographers Jasmin Leila Award). Recent and forthcoming publications include articles on sibling care and life transitions in Area, emotional interactions and an ethic of care in families affected by HIV and AIDS (with Felicity Thomas) in Emotion, Space and Society and caring relations in African migrant families in Population, Space and Place.

CRuth Evans 10/5/10. Please cite article as: Evans, R. (2010) 'Children's caring roles and responsibilities within the family in Africa', Geography Compass, 4(10): 1477-1496. 


\section{References}

Akintola, O. (2004). The Gendered Burden of Home-based Caregiving Policy Brief. Durban:

Health Economics and HIV/AIDS Research Division, University of KwaZulu-Natal.

[Online]. Retrieved on $28^{\text {th }}$ January 2010 from:

http://allafrica.com/download/resource/main/main/id/00010373.pdf.

Aldridge, J, and Becker, S. (2003). Children Caring for Parents with Mental Illness:

Perspectives of Young Carers, Parents and Professionals. Bristol: The Policy Press.

Ansell N. (2009). Childhood and the politics of scale: descaling children's geographies?

Progress in Human Geography 33(2), pp.190-209.

Ansell N. (2005). Children, Youth and Development. London: Routledge

Ansell, N. (2004). Secondary schooling and rural youth transitions in Lesotho and Zimbabwe. Youth and Society 36(2), pp. 183-202.

Backett-Milburn, K., Wilson, S., Bancroft, A., Cunningham-Burley, S. (2008). Challenging childhoods. Young people's accounts of 'getting by' in families with substance use problems. Childhood 15(4), pp.461-479.

Barnett, C. and Land, D. (2007). Geographies of generosity: beyond the 'moral turn', Geoforum 38, pp.1065-1075.

Bauman, L., Foster, G., Johnson Silver, E., Gamble, I. and Muchaneta, L. (2006). Children caring for their ill parents with HIV/AIDS. Vulnerable Children and Youth Studies 1(1), pp.114.

Bauman, L., Johnson Silver, E., Berman, R. and Gamble, I. (2009). Children as caregivers to their ill parents with AIDS. In Shifren, K., (ed.) How Caregiving Affects Development: 
Psychological Implications for Child, Adolescent and Adult Caregivers. Washington DC: American Psychological Association, pp.37-63.

Becker, S. (2007). Global perspectives on children's unpaid caregiving in the family: research and policy on 'young carers' in the UK, Australia, the USA and Sub-Saharan Africa. Global Social Policy 7(1), pp.23-50.

Becker, S. (2000). Young carers. In Davies, M., (ed.) The Blackwell Encyclopedia of Social Work. Oxford: Blackwell, p 378.

Becker, S., Aldridge, J. and Dearden, C. (1998). Young Carers and Their Families. Oxford: Blackwell Science.

Becker, F. and Becker, S. (2008). Young Adult Carers in the UK: Experiences, Needs and Services for Carers aged 16-24. London: Princess Royal Trust for Carers.

Bell, S. and Payne, R. (2009). Young people as agents in development processes: reconsidering perspectives for development geography. Third World Quarterly 30(5), pp.1027-1044.

Boris, N., Brown, L., Thurman, T., Rice, J., Snider, L., Nyirazinyoye, L. (2008). Depressive symptoms in youth heads of household in Rwanda. Archives of Pediatrics and Adolescent Medicine 162(9), pp.836-843.

Bourdillon, M. (2004). Children in Development. Progress in Development Studies 4(2), pp.99-113.

Bowlby, S., McKie, L., Gregory, S. and MacPherson, I. (2010) Interdependency and Care over the Lifecourse. Oxford: Routledge.

Bradley, C. (1993). Women's power, children's labor. Cross-Cultural Research 27 (1-2), pp.70-96.

CRuth Evans 10/5/10. Please cite article as: Evans, R. (2010) 'Children's caring roles and responsibilities within the family in Africa’, Geography Compass, 4(10): 1477-1496. 
Bray, R. (2009). A Literature Review on Child Carers in Angola, Nigeria, Uganda and Zimbabwe. Unpublished report. London: Save the Children UK.

Brydon, L. and Chant, S. (1989). Women in the Third World: Gender Issues in Rural and Urban Areas. Aldershot: Edward Elgar Publishing.

Cain, V. and Hofferth, S. (1989). Parental Choice of Self-Care for School-Age Children. Journal of Marriage and Family 51(1), pp. 65-77

Casper, L. and Kristin, E. (2004). Self-Care: Why Do Parents Leave Their Children Unsupervised? Demography 41(2), pp.285-301.

Chant, S. and Jones, G. (2005). Youth, gender and livelihoods in West Africa: perspectives from Ghana and The Gambia. Children's Geographies 3(2), pp. 185-199.

Chimwaza, A. and Watkins, S. (2004). Giving care to people with symptoms of AIDS in rural sub-Saharan Africa. AIDS Care 16(7), pp 795-807.

Christiansen C., Utas M, Vigh H. (2006). Youth(e)scapes. In Christiansen, C., Utas, M., Vigh, H., (eds.) Navigating Youth Generating Adulthood: Social Becoming in an African Context. Uppsala: Nordiska Afrikainstitutet, pp. 9-28.

Cicirelli, V. (1994). Sibling relationships in cross-cultural perspective. Journal of Marriage and the Family 56(1), pp.7-20.

Cluver, L. and Operario, D. (2008). Young carers for AIDS-unwell parents: mental health, physical health and education outcomes. Unpublished research information sheet, Centre for Evidence-based Intervention, Department of Social Policy and Social Work, Oxford University. See also Young Carers South Africa Project [online] accessed on $28^{\text {th }}$ January 2010 from: http://www.youngcarers.netau.net/index.html. 
Dearden, C. and Becker, S. (2004). Young Carers in the UK: The 2004 Report. London: Carers UK.

Dearden, C. and Becker, S. (1995). Young Carers: The Facts. Sutton: Reed Business

Publishing.

Dearden, C. and Becker, S. (1998). Young Carers in the United Kingdom: A Profile. London: Carers National Association.

De Boeck, F., and Honwana, A. (2005). Introduction: children and youth in Africa: agency, identity and place. In Honwana, A. and De Boeck, F., (eds.) Makers and Breakers: Children and Youth in Postcolonial Africa. Oxford: James Currey, pp.1-18.

Donald, D. and Clacherty, G. (2005). Developmental vulnerabilities and strengths of children living in child-headed households: a comparison with adult-headed households in equivalent impoverished communities. African Journal of AIDS Research 4(1), pp.21-28.

Esplen, E. (2009). Home-based carers mobilise to get their priorities heard. Gender and Development in Brief, BRIDGE Bulletin, 20, February [Online]. Retrieved on $15^{\text {th }}$ September 2009 from http://www.bridge.ids.ac.uk/docs/InBrief20_care.pdf.

Evans, B. (2008). Geographies of youth/young people. Geography Compass 2(5), pp.16591680.

Evans, R. (in press). Young caregiving and HIV in the UK: caring relationships and mobilities in African migrant families. Population, Space and Place DOI: 10.1002/psp.583. Evans, R. (forthcoming). “We are managing our own lives...”: Life transitions and care in sibling-headed households affected by AIDS in Tanzania and Uganda. Area.

Evans, R. (2005). Social networks, migration and care in Tanzania: caregivers' and children's resilience in coping with HIV/ AIDS. Journal of Children and Poverty 11(2), pp.111-129. 
Evans, R. and Becker, S. (2009). Children Caring for Parents with HIV and AIDS: Global Issues and Policy Responses. Bristol: The Policy Press.

Evans, R. and Thomas, F. (2009). Emotional interactions and an ethic of care: caring relations in families affected by HIV and AIDS. Emotions, Space and Society 2, pp.111-119. Foster, G., Makufa, C., Drew, R., and Kralovec, E. (1997). Factors leading to the establishment of child-headed households: the case of Zimbabwe. Health Transition Review, Supplement 2(7), pp.155-68.

Francis-Chizororo, M. (2008). The formation, constitution and social dynamics of orphaned child-headed households in rural Zimbabwe in the era of HIV/AIDS pandemic. Unpublished $\mathrm{PhD}$ thesis School of Geography and Geosciences University of St. Andrews, Scotland. [Online]. Retrieved on $28^{\text {th }}$ January 2010 from https://research-repository.st-andrews.ac.uk. Frank, J., Tatum, C. and Tucker, S. (1999). On Small Shoulders: Learning from the Experiences of Former Young Carers. London: The Children's Society.

Gaut, D. and Kieckhefer, G. (1988). Assessment of self-care agency in chronically ill adolescents. Journal of Adolescent Health Care 9(1), pp.55-60.

Germann, S. (2005). An exploratory study of quality of life and coping strategies of orphans living in child-headed households in the high HIV/AIDS prevalent city of Bulawayo, Zimbabwe. Unpublished PhD thesis University of South Africa.

Hopkins, P. and Pain, R. (2007). Geographies of age: thinking relationally. Area 39(3), pp.287-29.

Howard, S., Dryden, J. and Johnson, B. (1999). Childhood resilience: review and critique of the literature. Oxford Review of Education 25(3), pp 307-23. 
International Labour Organisation. (2006). The End of Child Labour: Within Reach, International Labour Conference. Geneva: 95th Session 2006 Report I (B), International Labour Office. [Online] Retrieved on $28^{\text {th }}$ January 2010 from:

http://www.ilo.org/public/english/standards/relm/ilc/ilc95/pdf/rep-i-b.pdf.

Katz, C. (1993). Growing circles/ closing circles: Limits on the spaces of knowing in rural Sudan and US cities. In Katz, C. and Monk, J., (eds.) Full Circles: Geographies of Women over the Life Course. London: Routledge, pp.88-106.

Katz, C. (2004). Growing Up Global: Economic Restructuring and Children's Everyday Lives. Minneapolis: University of Minnesota Press.

Kesby M., Gwanzura-Ottemoller, F., Chizororo, M. (2006). Theorising other, 'other childhoods': issues emerging from work on HIV in urban and rural Zimbabwe. Children's Geographies 4(2), pp.185-202.

Kielland, A. and Tovo, M. (2006). Children at Work: Child Labor Practices in Africa. Boulder: Lynne Rienner Publishers.

Koda, B. (2000). Democratisation of social relations at the household level: The participation of children and youth in Tanzania. In Creighton, C. and Omari, C.K., (eds.) Gender, Family and Work in Tanzania. Aldershot: Ashgate, pp.237-65.

Laird, S. (2005). International child welfare: deconstructing UNICEF's country programmes. Social Policy and Society 4(4), pp 457-66.

LeVine, R. Dixon, S., LeVine, S., Richman, A., Leiderman, P., Keefer, C., Brazelton, T. (1996). Child Care and Culture: Lessons from Africa. Cambridge University Press, New York.

CRuth Evans 10/5/10. Please cite article as: Evans, R. (2010) 'Children's caring roles and responsibilities within the family in Africa’, Geography Compass, 4(10): 1477-1496. 
Luzze, F. and Ssedyabule, D. (2004). The Nature of Child-Headed Households in Rakai

District, Uganda. Kampala: Lutheran World Federation.

McEwan, C. and Butler, R. (2007) 'Disability and development: different models, different places', Geography Compass, 1/3: 448-466.

Meintjes, H., Hall, K., Marera, D. and Boulle, A. (2010). Orphans of the AIDS epidemic? The extent, nature and circumstances of child-headed households in South Africa. AIDS Care 22(1), pp.40-49.

Momsen, J. (1991). Women and Development in the Third World. London: Routledge.

Momsen, J. (2004). Gender and Development. London: Routledge.

Morrow, R. (2005). A Profile of Known Young Carers and Identification and Snapshot of the Ones Who are Hidden. Perth: Curtin University of Technology.

Moser, C. (1989). Gender planning in the Third World: meeting practical and strategic needs. World Development 17(11), pp.1799-1825.

Newman, T. (2002a). "Young carers" and disabled parents: time for a change of direction? Disability and Society 17(6), pp 613-25.

Newman, T. (2002b). Promoting Resilience: a Review of Effective Strategies for Child Care Services. Exeter: Centre for Evidence-based Social Services, University of Exeter and Barnardo's.

Noddings, N. (1984) Caring: A Feminine Approach to Ethics and Moral Education. Berkeley: University of California Press.

Nyambedha, E., Wandibba, S. and Aagaard-Hansen, J. (2003). Changing patterns of orphan care due to the HIV epidemic in Western Kenya. Social Science and Medicine 57, pp.301-11. 
Ogden, J., Esim, S., and Grown, C. (2006). Expanding the care continuum for HIV/AIDS: bringing carers into focus. Health Policy and Planning 21(5), pp 333-42.

Oleke, C., Blystad, A. and Rekdal, O. (2005). "When the obvious brother is not there": political and cultural contexts of the orphan challenge in northern Uganda. Social Science and Medicine 61, pp.2628-2638.

Omari, C.K. and S. Mbilinyi. (1997). African Values and Child Rights: some cases from Tanzania. Dar es Salaam: Dar es Salaam University Press.

Peacock, D. and Weston, M. (2008). Men and care in the context of HIV and AIDS: structure, political will and greater male involvement. Geneva: United Nations Division for the Advancement of Women Expert Group Meeting on 'Equal sharing of responsibilities between men and women, including care-giving in the context of HIV/AIDS', Geneva, 6-9 October 2008. [Online]. Retrieved on $28^{\text {th }}$ January 2010 from http://www.un.org/womenwatch/daw/egm/equalsharing/EGM-ESOR-2008-EP-9\%20Dean\%20Peacock-Updated.pdf.

Panelli, R., Punch, S. and Robson, E. (eds.) (2007). Global Perspectives on Rural Childhood and Youth: Youth Rural Lives. London: Routledge.

Payne, R. (2009). Child-Headed Households in Zambia: from concepts to realities. Unpublished PhD thesis Department of Geography Royal Holloway University of London. Philo, C. (2000). 'The corner-stones of my world': editorial introduction to special issue on spaces of childhood. Childhood 7, pp.243-256.

Punch, S. (2002). Youth transitions and interdependent adult-child relations in rural Bolivia. Journal of Rural Studies 18, pp 123-33. 
Punch, S. (2001). Household division of labour: generation, gender, age, birth order and sibling composition. Work, Employment and Society 15(4), pp 803-23.

Robson, E. (2004a) Hidden child workers: young carers in Zimbabwe. Antipode 36(2), pp. $227-48$.

Robson, E. (2004b). Children at work in rural northern Nigeria: patterns of age, space and gender. Journal of Rural Studies 20, pp.193-210.

Robson, E. (2000). Invisible carers: young people in Zimbabwe's home-based healthcare. Area 32(1), pp 59-69.

Robson, E., Ansell, N., Huber, U.S., Gould, W. T. S. and van Blerk, L. (2006). Young caregivers in the context of the HIV/AIDS pandemic in sub-Saharan Africa. Population, Space and Place 12, pp.93-111.

Robson, E. and Ansell, N. (2000). Young carers in Southern Africa: exploring stories from Zimbabwean secondary school students. In Holloway, S. and Valentine, G., (eds.) Children's Geographies. London and New York: Routledge, pp.174-93.

Rutter, M. (1990). Psychosocial resilience and protective mechanisms. In Rolf, J., Masten, A., Cicchetti, D., Nuechterlein, K., and Weintraub, S., (eds.) Risk and Protective Factors in the Development of Psychopathology. Cambridge: Cambridge University Press, pp.181-214. Skovdal, M. and Ogutu, V. (2009). "I washed and fed my mother before going to school”: understanding the psychosocial wellbeing of children providing chronic care for adults affected by HIV/AIDS in Western Kenya. Globalization and Health, 5(8) [Online] Retrieved on $28^{\text {th }}$ January 2010 from http://www.globalizationandhealth.com/content/5/1/8. 
Skovdal, M., Ogutu, V., Aoro, C. and Cambell, C. (2009). Young carers as social actors: coping strategies of children caring for ailing or ageing guardian in Western Kenya. Social Science and Medicine, 69, pp.587-595.

Sparr, P. (1994). Mortgaging Women's Lives: Feminist Critiques of Structural Adjustment, London: Zed Books.

Steinberg, M., Johnson, S., Schierhout, G., Ndegwa, D., Hall, K., Russell, B. and Morgan, J. (2002). Hitting Home: How Households Cope with the Impact of the HIV/AIDS Epidemic - A Survey of Households Affected by HIV/AIDS in South Africa, Washington DC: Henry J Kaiser Family Foundation.

Thomas, F. (2006). Stigma, fatigue and social breakdown: exploring the impacts of HIV/AIDS on patient and carer wellbeing in the Caprivi region, Namibia. Social Science and Medicine 63, pp 3174-87.

Thomas, N., Stainton, T., Jackson, S., Cheung, W.Y., Doubtfire, S. and Webb, A. (2003). "Your friends don't understand": invisibility and unmet need in the lives of "young carers". Child and Family Social Work 8(1), pp. 35-46.

Thurman T., Snider, L, Boris, N., Kalisa, E. Nyirazinyoye, L. and Brown, L. (2008). "Barriers to the community support of orphans and vulnerable youth in Rwanda", Social Science and Medicine 66, pp.1557-1567.

Thurman, T, Snider, L., Boris, N., Kalisa, E., Mugarira, E., Ntaganira, J., and Brown, L. (2006). Psychosocial support and marginalization of youth-headed households in Rwanda. AIDS Care 18(3), pp.220-229.

Tronto, J. (1993). Moral Boundaries. A Political Argument for an Ethic of Care. New York and London: Routledge. 
Ungerson, C. (1983). Why do women care? In Finch, J. and Groves, D. (eds.) A Labour of Love: Women, Work and Caring. London: Routledge and Kegan Paul, pp 31-49.

United Nations Children's Fund (2008). State of the World's Children 2009. UNICEF, New York. [Online]. Retrieved on $28^{\text {th }}$ January 2010 from:

http://www.unicef.org/sowc09/docs/SOWC09-FullReport-EN.pdf.

Valentine, G. (2008). The ties that bind: towards geographies of intimacy. Geography Compass, 2(6), pp.2097-2110.

van Blerk, L. (2008). Poverty, migration and sex work: youth transitions in Ethiopia. Area 40(2) 245-253.

van Blerk, L. and Ansell, N. (2007). Alternative strategies for care giving in the context of AIDS in Southern Africa: complex strategies for care. Journal of International Development, 19, pp 865-84.

Vanderbeck, R. (2007). Intergenerational geographies: age relations, segregation and reengagements, Geography Compass 1(2), pp.200-221.

Weisner, T. (1982). Sibling interdependence and child caretaking: a cross-cultural view. In Lamb, M. and Sutton-Smith, B., (eds.) Sibling Relationships: their nature and significance across the lifespan. London: Lawrence Erlbaum Associates, pp.305-327.

World Health Organisation. (2009). Towards Universal Access: Scaling Up Priority HIV/AIDS Interventions in the Health Sector, Progress Report 2009, Geneva: World Health Organization. [Online]. Retrieved on $28^{\text {th }}$ January 2010 from: http://www.who.int/hiv/pub/tuapr_2009_en.pdf. Yeo, R. and Moore, K. (2003) 'Including disabled people in poverty reduction work: "Nothing about us, without us", World Development, 31(3): 571-590. 
Young, L. and Ansell, N. (2003). Fluid households, complex families: the impacts of children's migration as a response to HIV/AIDS in Southern Africa. The Professional Geographer 55(4), pp 464-76.

CRuth Evans 10/5/10. Please cite article as: Evans, R. (2010) 'Children's caring roles and responsibilities within the family in Africa', Geography Compass, 4(10): 1477-1496. 